\title{
Role of chronic hepatitis in development of thalassaemic liver disease
}

\author{
G. MASERA, G. JEAN, G. GAZZOLA, and M. NOVAKOVA \\ From Clinica Pediatrica dell'Università degli Studi, and Ospedale Caduti Bollatesi, Milan, Italy
}

\begin{abstract}
Masera, G., Jean, G., Gazzolu, G., and Novakova, M. (1976). Archives of Disease in Childhood, 51, 680. Role of chronic hepatitis in development of thalassaemic liver disease. Liver function and the presence of $\mathrm{HBsAg}$ and anti-HBsAg were studied in 90 hypertransfused thalassaemic children. Increased serum transaminases were found in 62 patients, and persisted for more than 6 months in 45 cases. Liver biopsy in this latter group led to a diagnosis of 14 cases of chronic persistent hepatitis, 9 cases of aggressive hepatitis, and 3 cases of hepatic fibrosis. In Italy thalassaemic children undergoing hypertransfusion therapy frequently encounter SH virus infection, with a consequent hepatitis that is generally anicteric and unrecognized unless systematically sought. In a liver already stressed by the concomitant iron overload, hepatitis infection might thus play a key role in the evolution of cirrhosis which frequently affects thalassaemics.
\end{abstract}

The picture of thalassaemia has markedly changed in the last few years because of a more correct transfusion therapy. Serious cardiopathy is seen later in the course of the disease, whereas more thalassaemics are succumbing to fatal hepatic cirrhosis (Beltrami and Nenci, 1969; Ellis, Schulman, and Smith, 1954; Giraud, Orsini, and Muratore, 1959; Panizon and Vullo, 1957; Witzleben and Wyatt, 1961). Hepatotoxic factors to which the liver of the thalassaemic child may be exposed include iron overload, chronic hypoxia, hepatic stasis, protein deficiency, and repeated viral infection, particularly with SH virus but knowledge is scanty on the role of each of these on the evolution of liver cirrhosis. What knowledge there is is based on necropsy findings, and only recently has liver biopsy in vivo allowed the systematic study of the development of liver disease (Risdon, Flynn, and Barry, 1973; Masera and Jean, 1973; Barry et al., 1974). From these studies it has emerged that inflammatory changes develop in the liver compatible with a diagnosis of chronic hepatitis (Masera and Jean, 1973; Diebold and Camilleri, 1974). Furthermore, the observations of Economidou et al. (1970), Vierucci et al. (1972), Kattamis et al. (1974), and ourselves (Masera and Jean, 1973) have shown a high incidence of HBsAg and anti-HBsAg in hypertrans-

Received 28 November 1975. fused thalassaemic patients. While the data suggest that serum hepatitis is a frequent side effect of therapy in thalassaemia, it is not known whether the hepatitis is a limited episode or whether such infection is a decisive influence in the development of liver cirrhosis. The aim of this paper is to investigate the pathogenesis of histological lesions of liver in thalassaemia and to characterize their evolution in thalassaemic children.

\section{Methods}

The 90 children between 1 and 14 years of age included in this study, all of whom were homozygous for $\beta$-thalassaemia, have been followed during the course of treatment for at least 4 years. They were transfused with packed red cells every 20-30 days in order to maintain $\mathrm{Hb}$ above 7.5-8 g/dl. From 1970 all blood donors have been routinely examined for the presence of HBsAg.* During the first 2 years of observations, HBsAg, anti-HBsAg, and serum transaminases were determined two or three times a year in these patients. The methods used have varied during this 4-year period to take advantage of technical developments, and have included successively the immunodiffusion technique (Del Prete, Costantino, and Doglia, 1970) modified according to Prince, and two methods of immuno-osmoelectrophoresis (Costantino et al., 1972).

*In Italy the search fo: $\mathrm{HBsAg}$ in blood donors began in several medical centres in 1970, but from 1973 this testing has been performed in the majority of transfusion centres. 
Where serum transaminases were much increased, further biochemical tests were made, total and direct serum bilirubin, alkaline phosphatase, serum proteins (total and fractionated), 45-minute BSP retention, immunoglobulin levels, and the presence of LE factor, antinuclear factors, smooth muscle antibodies (immunofluorescence-indirect method) and migration inhibition factor (MIF) (Soborg and Bendixen, 1967). Liver biopsy was carried out in patients with raised serum transaminase levels for more than 6 months (Chalmers and Alter, 1971); liver specimens were fixed in Bouin's liquid and in paraffin; these preparations were then stained with $\mathrm{H} \& \mathrm{E}$ with silver impregnation (Gomori) and by Perls's method.

The characteristic histological picture of a thalassaemic liver, with an intense haemosiderosis, progressive fibrosis, and the presence of haemopoietic foci, made it necessary to evaluate the inflammatory status of each specimen using precise parameters of aggresiveness and chronicity of the hepatic lesion (Desmet and De Groote, 1974; Baggenstoss et al., 1972; Scheuer, 1968).

Indices of aggressiveness. The extension of necrosis was graded as follows: focal necrosis (cellular pleomorphism, Councilman's bodies); the bridging effect; submassive necrosis (involvement of portions of adjacent lobules with evidence of piecemeal necrosis).

Indices of chronicity. The disproportionate enlargement of the portal spaces from which fibrotic septa arise, interlobularly or taking the place of entire hepatic lobules, these septa being more or less infiltrated by inflammatory cells which tend to invade the surrounding parenchyma with phenomena of piecemeal necrosis; an increase in number of bile canaliculi.

On the basis of such elements we have classified our cases as either chronic persistent hepatitis, chronic aggressive hepatitis, or fibrosis. It is likely that this histological picture, due to a multifactorial pathogenesis, has a prognostic and developmental significance different from similar histological patterns seen in nonthalassaemic patients.

\section{Results}

Increase in serum transaminases. Systematic monitoring (every 20-30 days) of SGOT and SGPT levels led to the discovery of increase in these enzymes to more than three times the normal values in a large proportion of cases (62/90). 3 of the cases developed a typical icteric hepatitis, the features of which were no different from those of hepatitis in nonthalassaemic children. All 3 cases were $\mathrm{HBsAg}$ positive, the first being so for only a few weeks and the other 2 for 34 and 36 months, respectively. In the remaining 59 cases of anicteric liver disease there was no clinical evidence to suggest an acute liver involvement. In 45 of the 90 cases raised transaminases persisted for from 9 to 24 months.
Incidence of HBsAg and anti-HBsAg. Of the 90 cases examined, $9(10 \%)$ were $\mathrm{HBsAg}$ positive. Transient evidence of $\mathrm{HBsAg}$ was found in 7 cases, but only in 2 cases was this antigen present a long time (34 and 36 months, respectively). Anti-HBsAg positivity was more frequently shown for prolonged periods (13 out of the 28 cases), yet this antibody was present for only a few weeks in the other 15 cases (Gazzola et al., 1974).

Liver biopsy (Table I). Liver biopsy was performed in 26 patients who had evidence of abnormally high transaminase levels for more than 6 months. The lesions were multiple and varied somewhat in different biopsy specimens from the same patient.

Hepatitis (Fig. 1). In 23 out of the 26 cases inflammatory infiltrates and cellular necrosis were present. In 14 cases the diagnosis of persistent hepatitis was made since the inflammatory infiltrates were mainly in the portal spaces and in the fibrous tissue without invasion of the surrounding hepatic parenchyma. Frequently, small areas of focal necrosis with Councilman's bodies and mononuclear infiltrates were present within the hepatic lobule, but evidence of piecemeal necrosis was not seen. On the contrary, in 9 of the remaining cases piecemeal necrosis, bridging effect, areas of marked focal and/or submassive necrosis were observed accompanied by active or passive septa (Desmet and De Groote, 1974). In these cases the diagnosis of aggressive hepatitis was made.

Fibrosis (Fig. 2). In all 26 cases fibrosis was conspicuous, involving primarily the portal spaces from which fibrotic interlobular septa arise. Generally, the connective tissue bands, newlyformed or derived from the collapse of original reticulum, had mononuclear cell infiltrates. Only in 3 of those patients whose specimens were diagnosed as showing hepatic fibrosis were the fibrotic phenomena predominant over the inflammatory aspects. In these cases the bile canaliculi were increased in number, without, however, enough evidence of pseudolobular regeneration to permit a diagnosis of cirrhosis.

Siderosis. In all 26 cases massive siderotic pigmentation was noted $(++++$ according to the scale of Barry, 1974) and involved the hepatocytes, the Kupffer cells, and the macrophages in the portal spaces as well as in the fibrous tissue. In certain cases that had received desferrioxamine-B the siderosis was more prominent near the portal spaces than in the centre of the hepatic lobule. 
TABLE I

Details of 26 biopsied patients

\begin{tabular}{|c|c|c|c|c|c|c|c|c|c|}
\hline $\begin{array}{l}\text { Case } \\
\text { no. }\end{array}$ & Sex & $\begin{array}{l}\text { Age } \\
(\mathrm{yr})\end{array}$ & HBsAg & $\begin{array}{l}\text { Anti- } \\
\text { HBsAg }\end{array}$ & $\begin{array}{c}\text { Icteric } \\
\text { hepatitis }\end{array}$ & $\underset{\text { transaminases }}{\text { Serum }}$ & $\begin{array}{c}\text { Smooth } \\
\text { muscle } \\
\text { antibodies }\end{array}$ & MIF & $\begin{array}{r}\text { Liver } \\
\text { biopsy }\end{array}$ \\
\hline $\begin{array}{r}1 \\
2 \\
3 \\
4 \\
5 \\
6 \\
7 \\
8 \\
9 \\
10 \\
11 \\
12 \\
13 \\
14 \\
15 \\
16 \\
17 \\
18 \\
19 \\
20 \\
21 \\
22 \\
23 \\
24 \\
25 \\
26\end{array}$ & $\begin{array}{l}\mathbf{M} \\
\mathbf{M} \\
\mathbf{M} \\
\mathbf{M} \\
\mathbf{F} \\
\mathbf{M} \\
\mathbf{M} \\
\mathbf{M} \\
\mathbf{F} \\
\mathbf{M} \\
\mathbf{M} \\
\mathbf{F} \\
\mathbf{F} \\
\mathbf{F} \\
\mathbf{F} \\
\mathbf{F} \\
\mathbf{M} \\
\mathbf{F} \\
\mathbf{F} \\
\mathbf{M} \\
\mathbf{F} \\
\mathbf{M} \\
\mathbf{F} \\
\mathbf{M} \\
\mathbf{F} \\
\mathbf{F}\end{array}$ & $\begin{array}{r}14 \\
7 \\
10 \\
9 \\
6 \\
12 \\
12 \\
8 \\
14 \\
10 \\
9 \\
13 \\
12 \\
14 \\
11 \\
13 \\
6 \\
9 \\
14 \\
6 \\
12 \\
8 \\
8 \\
5 \\
14 \\
12\end{array}$ & $\begin{array}{l}+ \\
+ \\
++ \\
++ \\
++ \\
= \\
= \\
= \\
- \\
- \\
= \\
= \\
= \\
= \\
- \\
- \\
= \\
- \\
= \\
= \\
= \\
-\end{array}$ & $\begin{array}{l}- \\
- \\
- \\
- \\
+ \\
+ \\
+ \\
+ \\
+ \\
+ \\
+ \\
++ \\
++ \\
++ \\
++ \\
++ \\
++ \\
++ \\
++ \\
+ \\
- \\
- \\
- \\
-\end{array}$ & $\begin{array}{l}\text { No } \\
\text { Yes } \\
\text { No } \\
\text { No } \\
\text { No } \\
\text { No } \\
\text { No } \\
\text { No } \\
\text { No } \\
\text { No } \\
\text { No } \\
\text { No } \\
\text { No } \\
\text { No } \\
\text { No } \\
\text { No } \\
\text { No } \\
\text { No } \\
\text { No } \\
\text { No } \\
\text { No } \\
\text { No } \\
\text { No } \\
\text { No } \\
\text { No } \\
\text { No }\end{array}$ & $\begin{array}{r}13 \\
14 \\
12 \\
14 \\
13 \\
22 \\
13 \\
21 \\
10 \\
24 \\
16 \\
18 \\
14 \\
9 \\
13 \\
13 \\
11 \\
17 \\
14 \\
11 \\
10 \\
10 \\
18 \\
8 \\
16 \\
12\end{array}$ & $\begin{array}{l}+ \\
\pm \\
- \\
\pm \\
\pm \\
\pm \\
- \\
- \\
- \\
+ \\
- \\
- \\
- \\
+ \\
+ \\
+ \\
+ \\
\\
+ \\
++ \\
+\end{array}$ & $\begin{array}{l}+ \\
+ \\
+ \\
+ \\
- \\
- \\
- \\
- \\
+ \\
+ \\
+\end{array}$ & $\begin{array}{l}\text { HF } \\
\text { CPH } \\
\text { CPH } \\
\text { CPH } \\
\text { CAH } \\
\text { CAH } \\
\text { CAH } \\
\text { CAH } \\
\text { HF } \\
\text { CPH } \\
\text { CPH } \\
\text { CAH } \\
\text { CAH } \\
\text { CAH } \\
\text { HF } \\
\text { CPH } \\
\text { CPH } \\
\text { CAH } \\
\text { CPH } \\
\text { CPH } \\
\text { CPH } \\
\text { CPH } \\
\text { CAH } \\
\text { CPH } \\
\text { CPH } \\
\text { CPH }\end{array}$ \\
\hline
\end{tabular}

*Serum transaminases: length of the increase in months.

,$+ \mathrm{HbsAg}$ or anti-HBsAg positive longer than 3 months; ++, $\mathrm{HBsAg}$ or anti-HBsAg positive transiently; CPH, chronic persistent hepatitis; $\mathrm{CAH}$, chronic aggressive hepatitis; $\mathrm{HF}$, hepatic fibrosis; MIF, migration inhibition factor.

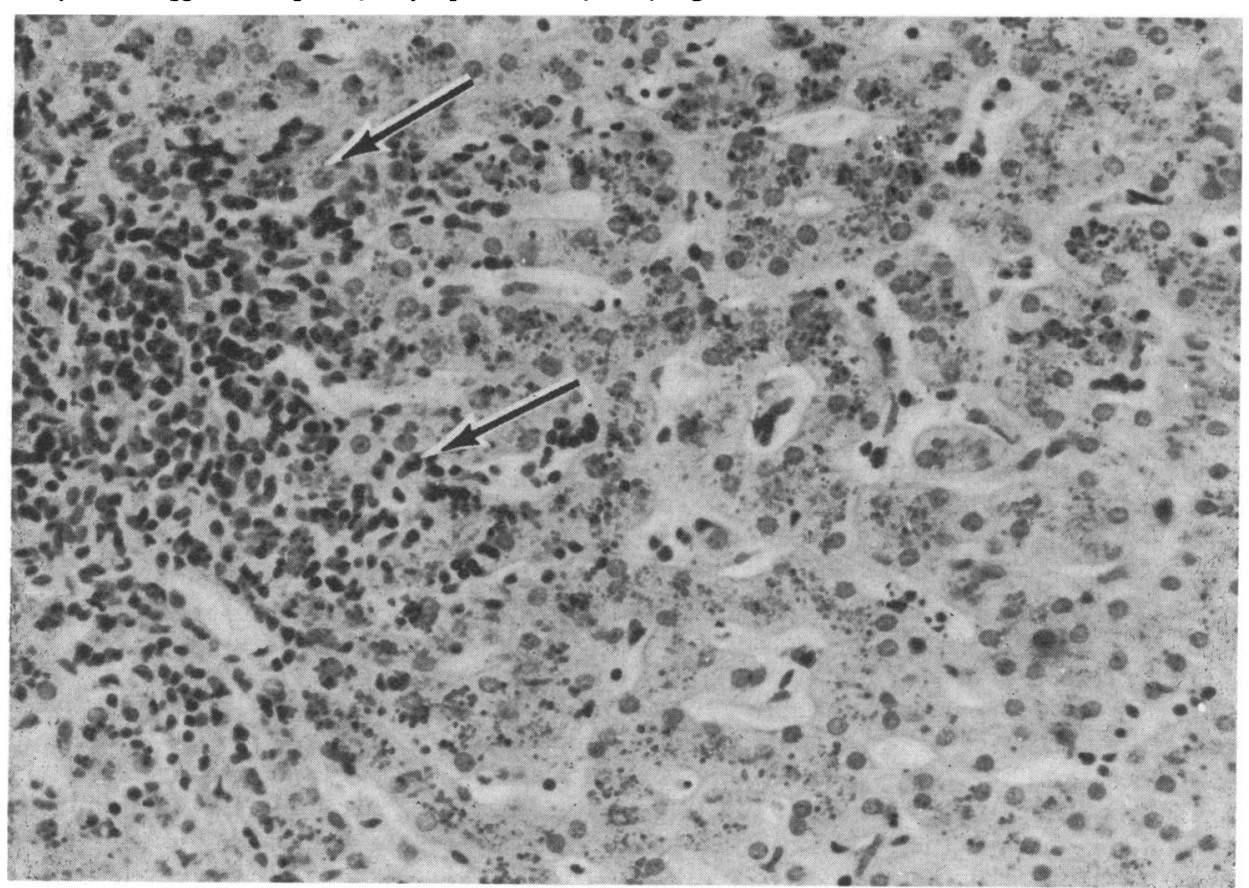

FIG. 1.-Inflammatory infiltrate and piece-meal necrosis (arrows). Marked hyperplasia and hypertrophy of the Kupffer cells. Evidence of iron overload. (H. and $E . \times 260$.) 


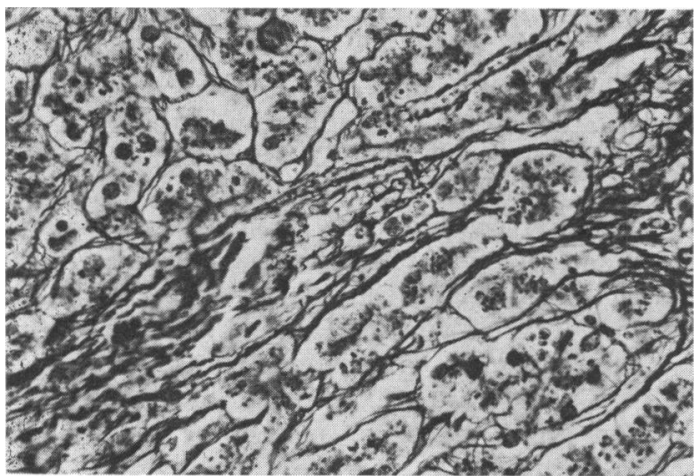

FIG. 2.- Silver impregnation. Collapse of the reticulum and the initial formation of fibrotic septa.

(Gomori's. $\times 165$.)

It is interesting to note that with $\mathrm{H} \& \mathrm{E}$ staining the Councilman's bodies appeared yellowish and not pink, indicating an even greater iron overload in the necrotic hepatocytes.

Areas of hepatic haemopoiesis (Fig. 3). Evidence of haemopoiesis was present in all cases. These areas were localized within the hepatic lobule and contained erythrobiasts and megakaryocytes; their localization within the hepatic lobule and their composition (lacking myelocytes) being similar to that found in fetal liver (Diebold and Camilleri, 1974; Du Bois, 1963).

Summarizing conclusions, in hypertransfused thalassaemic patients signs of localized hepatitis, primarily in the portal spaces and periportal zones, are superimposed on a liver more or less extensively fibrotic. Less frequently the inflammatory infiltrate is located more towards the centre of the hepatic lobule, suggesting a histological picture like that described as chronic lobular hepatitis (Popper and Schaffner, 1971).

Correlation between histological findings and HBsAg and anti-HBsAg (Table II). Of the 14 cases with the histological picture of persistent hepatitis, only 3 were $\mathrm{HBsAg}$ positive and 6 antiHBsAg positive. On the other hand, in 8 of the 9 cases diagnosed as aggressive hepatitis both $\mathrm{HBsAg}$ and anti-HBsAg positivity were found, an indication that these patients had been infected with $\mathrm{SH}$ virus.

Immunological investigations (Table I). Among the immunological tests made, smooth-

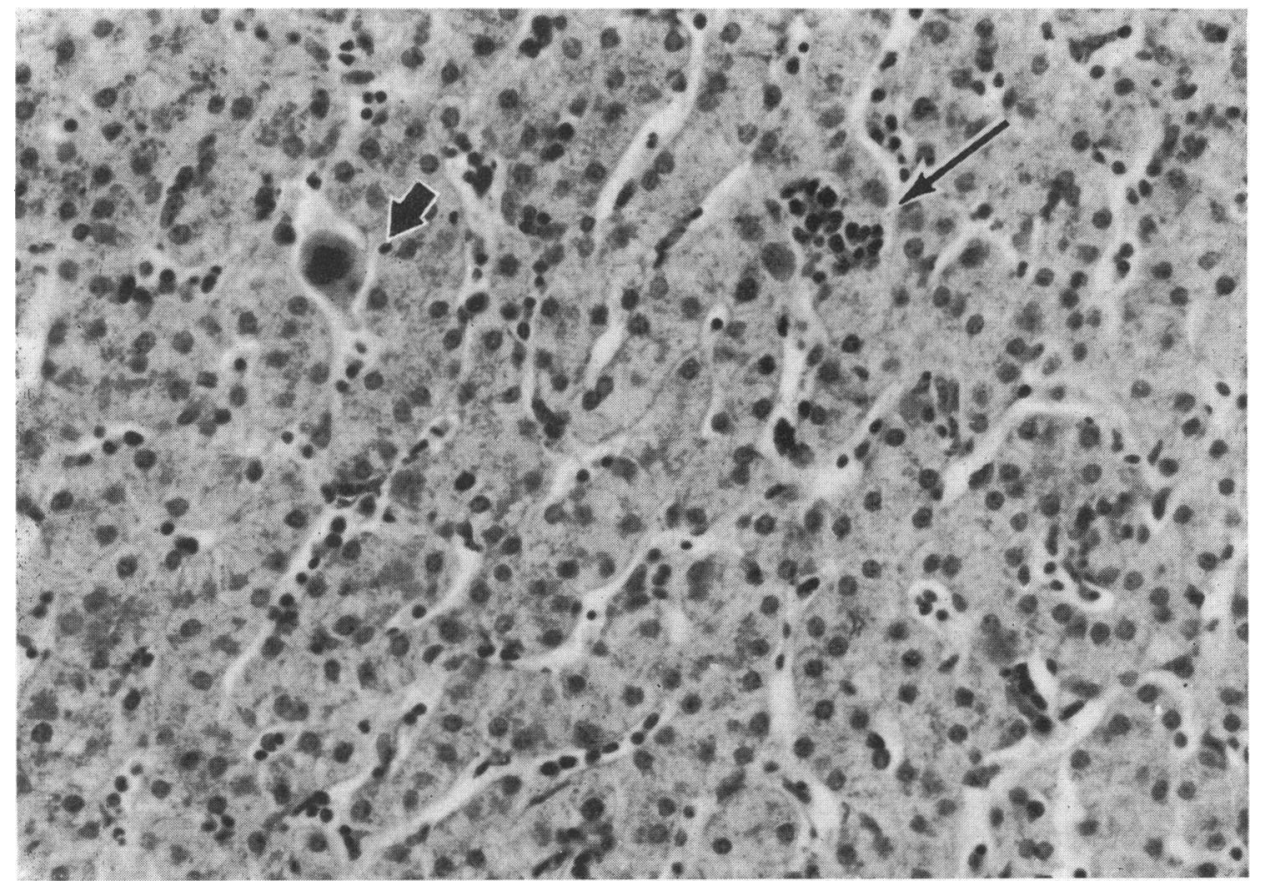

FIG. 3.- Hepatic foci of haemopoiesis with clusters of erythroblasts (arrow) and with erythroblasts and a megakaryocyte (arrow head) along the hepatic sinusoids. (H. and $E . \times 260$.) 
TABLE II

Correlation between histological findings and $\mathrm{HBs} A \mathrm{~g}$ and anti-HBs Ag in 26 patients

\begin{tabular}{|c|c|c|c|}
\hline & \multicolumn{3}{|c|}{ Liver biopsy } \\
\hline & $\begin{array}{l}\text { Chronic } \\
\text { persistent } \\
\text { hepatitis }\end{array}$ & $\begin{array}{l}\text { Chronic } \\
\text { aggressive } \\
\text { hepatitis }\end{array}$ & $\begin{array}{c}\text { Hepatic } \\
\text { fibrosis }\end{array}$ \\
\hline $\begin{array}{l}\text { HBsAg } \\
\text { Anti-HBsAg } \\
\text { Negatives }\end{array}$ & $\begin{array}{l}3 \\
6 \\
5\end{array}$ & $\begin{array}{l}1 \\
7 \\
1\end{array}$ & $\begin{array}{l}1 \\
2 \\
-\end{array}$ \\
\hline Total & 14 & 9 & 3 \\
\hline
\end{tabular}

muscle antibodies were occasionally shown, but antinuclear factor was never noted. Interestingly, the migration inhibition factor was almost always positive in those cases with histological evidence of chronic aggressive hepatitis. It was not possible to formulate any conclusions on the modification of serum proteins since they are already considerably altered in thalassaemia, even in the absence of liver involvement.

\section{Discussion}

The study of the liver in hypertransfused thalassaemic children has generally been performed on post-mortem specimens (Beltrami and Nenci, 1969; Ellis et al., 1954; Giraud et al., 1959; Panizon and Vullo, 1957; Witzleben and Wyatt, 1961). These investigations have shown that the hepatic insufficiency of thalassaemics is due to the presence of haemochromatosis with fibrosis and hepatic cirrhosis. A few studies have been made using biopsy material (Risdon et al., 1973; Masera and Jean, 1973; Barry et al., 1974) but the initial stages of the hepatic lesions are poorly understood. Investigators have mainly concentrated on the massive deposits of ferrous pigment; sporadic reports have called attention to the mononuclear cell infiltrates, probably evidence of an inflammatory component in this hepatopathy (Beltrami and Nenci, 1969; Masera and Jean, 1973; Diebold and Camilleri, 1974; Necheles, 1974). Attempts to delay the development of hepatic cirrhosis have been largely through the use of iron-chelating compounds (Barry et al., 1974). Yet the problem of cirrhosis should not be entirely attributed to pigment overload. In animal experiments it has not been possible to cause cirrhosis by administering massive doses of iron alone; only if another hepatotoxic factor (ethionine, carbon tetrachloride) is added to treatment will experimental cirrhosis develop (Goldberg and Smith, 1960; Kent et al., 1964; Nath, Sood, and Nayak, 1972; Orfei et al., 1968). These facts prompted us to consider other factors which might exert harmful effects on the liver of hypertransfused thalassaemic children. Previous reports have shown frequent $\mathrm{SH}$ virus infection in thalassaemics (Economidou et al., 1970; Kattamis et al., 1974; Masera and Jean, 1973; Vierucci et al., 1972) and undoubtedly repeated transfusion must expose the patients to infection with other hepatotropic viruses including cytomegalovirus (Prince et al., 1971) and other unidentified viruses responsible for a hepatitis with a prolonged incubation (Finstone et al., 1975). It must also be considered that thalassaemic children might be more susceptible to hepatitis caused by virus $A$.

The hypothesis of a hepatitis causing hepatic damage, at least in some thalassaemics, has been confirmed by our findings. $\mathrm{HBsAg}$ and anti$\mathrm{HBsAg}$ were frequently shown in our thalassaemic patients, as in previous studies. Our findings relate to the studies carried out in Italy (Vierucci et al., 1972), whereas in Greece (Kattamis et al., 1974) the incidence of $\mathrm{Au}$ antigen in the normal population is higher (Italy: 1\%, Ceppellini et al., 1970; 2\%, Rossi and Albrisi, 1974; Greece: 3\%, Hadziyannis et al., 1970) than in other countries. A transient or prolonged rise in serum transaminases was observed in 62 out of 90 of our patients, of which only 3 had symptoms of acute icteric hepatitis; the diagnosis of hepatitis would have been overlooked in the other cases if the appropriate investigation had not been undertaken.

In 23 of the 26 patients who underwent liver biopsy evidence of chronic persistent or aggressive hepatitis was found. In chronic aggressive hepatitis the presence of $\mathrm{HBsAg}$ or anti-HBsAg was shown in 8 of 9 patients. In some of the patients nonspecific immunological changes (smooth muscle antibodies, rheumatoid factor, migration inhibition factor) were noted such as are often seen in chronic aggressive hepatitis. These observations support the hypothesis that a chronic hepatitis contributes to the development of the liver disease in a large number of thalassaemic children who have received transfusion therapy.

The various forms of chronic hepatitis seen in thalassaemic children have special features which are probably due to the gross iron overload. This iron might favour extension of the hepatic necrosis caused by virus or might prevent regeneration of the hepatocytes primitively injured. The liberation of ferric pigment in the inflamed tissue would also lead to a more intensive fibroblastic proliferation, and so help to promote cirrhosis.

Regarding the therapeutic implications of these observations, chelation therapy is logical and its 
efficacy proven (Barry et al., 1974). Steroid therapy may be of some benefit in particular cases; for instance, those characterized by a histological picture of chronic aggressivity. At present we are studying serial liver biopsies of patients with chronic aggressive hepatitis under steroid therapy, and hope to determine whether this type of therapy is capable of slowing the course of liver disease towards cirrhosis.

Finally, in order to prevent infection, transfused blood components must not contain hepatitis virus. This requires strict selection and screening of blood donors, more precise detection of $\mathrm{HBsAg}$ and anti$\mathrm{HBsAg}$, and the use of frozen blood.

\section{REFERENCES}

Baggenstoss, A. H., Soloway, R. D., Summerskill, W. H. J., Elveback, L. R., and Schoenfield, L. J. (1972). Chronic active liver disease. The range of histologic lesions, their response to treatment, and evolution. Human Pathology, 3, 183.

Barry, M. (1974). Liver iron concentration, stainable iron, and total body storage iron. Gut, 15, 411.

Barry, M., Flynn, D. M., Letsky, E. A., and Risdon, R. A. (1974). Long-term chelation therapy in thalassaemia major; effect on liver iron concentration, liver histology, and clinical progress. British Medical fournal, $2,16$.

Beltrami, C. A., and Nenci, I. (1969). Per una patogenesi epatitica della sclerosi e della cirrosi epatica nei Cooleyani. Rivista di Patologia Clinica e Sperimentale, 10, 165.

Ceppellini, R., Bedarida, G., Carbonara, A. O., Trinchieri, G., and Filippi, G. (1970). High frequency and family clustering of $\mathrm{Au}$ antigen in some Italian populations. Symposium sull' Epatite Virale, p. 53. Minerva Medica, Turin.

Chalmers, T. C., and Alter, H. J. (1971). Management of the asymptomatic carrier of the hepatitis-associated (Australia) antigen. New England fournal of Medicine, 285, 613.

Costantino, D., Del Prete, S., Doglia, M., Moroni, G. A., Gianotti, G. A., and Barbarani, V. (1972). Hepatitis associated antigens and placenta barrier. Italian fournal of Immunology and Immunopathology, 3, 39.

Del Prete, S., Costantino, D., and Doglia, M. (1970). Tecnica per la dimostrazione dell' antigene epatitico Australia. Gazzetta Sanitaria, 41, 69.

Desmet, V. J., and De Groote, H. (1974). Histological diagnosis of viral hepatitis. Clinics in Gastroenterology, 3, 337.

Diebold, J., and Camilleri, J. P. (1974). Foie et Affections du Sang, pp. 1, 149. Masson, Paris.

Du Bois, A. M. (1963). The embryonic liver. The Liver, p. 1. Ed. by C. Rouiller. Academic Press, New York.

Economidou, J., Costantoulakis, M., Augustaki, O., Taylor, P. E., Zuckerman, A. J., Baines, P. M., and Bryceson, M. A. (1970). The incidence of hepatitis-associated antigen and antibody in patients with thalassemia in Greece. Vox Sanguinis, 19, 401.

Ellis, J. T., Schulman, I., and Smith, C. H., (1954). Generalized siderosis with fibrosis of liver and pancreas in Cooley's (Mediterranean) anemia. With observations on the pathogenesis of the siderosis and fibrosis. American fournal of Pathology, 30, 287.

Finstone, S. M., Kapikian, A. Z., Purcell, R. H., Alter, H. J., and Holland, P. V. (1975). Transfusion-associated hepatitis not due to viral hepatitis type A or B. New England fournal of Medicine, 292, 767.

Gazzola, G., Novakova, M., Masera, G., Moroni, G. A., and Gianotti, G. A. (1974). Importanza dello studio dell'HBAg ed anti-HBAg nel bambion talassemico politrasfuso. Trasfusione del Sangue, 18, 545.

Giraud, P., Orsini, A., and Muratore, R. (1959). Le foie dans la maladie de Cooley. Pédiatrie, 14, 125.

Goldberg, L., and Smith, J. P. (1960). Iron overloading and hepatic vulnerability. American fournal of Pathology, 36, 125.

Hadziyannis, S., Merikas, G., Afroudikas, A., Panetsos, S., and Moussouros, A. (1970). Observations on Australia (Au) antigen in Greece. Iatriki, 18, 221.

Kattamis, C., Syriopoulou, V., Davri-Karamouzi, Y., Demetriou, D., and Matsaniotis, N. (1974). Prevalance of $\mathrm{Au}-\mathrm{Ag}$ and $\mathrm{Au}-\mathrm{Ab}$ in transfused children with thalassaemia in Greece. Archives of Disease in Childhood, 49, 450.

Kent, G., Voloni, F. I., Minick, O. T., Orfei, E., and De La Huerga, J. (1964). Effect of iron loading upon the formation of collagen in the hepatic injury induced by carbon tetracloride. American Fournal of Pathology, 45, 129.

Masera, G., and Jean, G. (1973). La patologia epatica nella talassemia. Prospettive in Pediatria, 3, 379.

Nath, I., Sood, S. K., and Nayak, N. C. (1972). Experimental siderosis and liver injury in Rhesus monkey. Fournal of Pathology, 106, 103.

Necheles, T. F. (1974). Endocrine function in thalassemia major. (Discussion.) Annals of the New York Academy of Sciences, 232, 361 .

Orfei, E., Volini, F. I., Madera-Orsini, F., Minick, O. T., and Kent, G. (1968). Effect of iron loading on the hepatic injury induced by ethionine. American fournal of Pathology, 52, 547.

Panizon, F., and Vullo, C. (1957). Sulla evoluzione della siderosi e fibrosi epatica nella malattia di Cooley. Acta Pediatrica Latina, $10,71$.

Popper, H., and Schafiner, F. (1971). The vocabulary of chronic hepatitis. New England fournal of Medicine, 284, 1154.

Prince, A. M., Szmuness, W., Millan, S. J. and David, D. S. (1971). A serologic study of cytomegalovirus infections associated with blood transfusions. New England fournal of Medicine, 284, 1125.

Ridson, R. A., Flynn, D. M., and Barry, M. (1973). The relation between liver iron concentration and liver damage in transfusional iron overload in thalassaemia and the effect of chelation therapy. Gut, 14, 421.

Rossi, U., and Albrisi, L. (1974). La situazione attuale in Italia della ricerca dell'antigene Australia nei donatori di sangue. Analisi dei dati derivanti dalle risposte ad un questionario informativo. Transfusione del Sangue, 19, Suppl. 4, 451.

Scheuer, P. J. (1968). Liver biopsy interpretation. Baillière, Tindall and Cassell, London.

Soborg, M., and Bendixen, M. (1967). Human lymphocyte migration as a parameter of hypersensitivity. Acta Medica Scandinavica, 181, 247.

Vierucci, A., London, W. T., Blumberg, B. S., Sutnick, A. I., and Ragazzini, F. (1972). Australia antigen and antibody in transfused children with thalassaemia. Archives of Disease in Childhood, 47, 760.

Witzleben, C. L., and Wyatt, J. P. (1961). The effect of long survival on the pathology of thalassaemia major. Fournal of Pathology and Bacteriology, 82, 1.

Correspondence to Dr. G. Masera, Clinica Pediatrica dell' Università degli Studi, Via Commenda 9, Milano, Italy. 